\title{
Promotion And Retention Of African American Accountants In The 21st Century US Public Accounting Profession: A Summary Of Findings And A Call For Action
}

Louis J. Stewart, Howard University, USA Jean Wells, Howard University, USA Frank Ross, Howard University, USA

\begin{abstract}
While African - American CPAs have experienced some considerable progress in the US public accounting profession over the past thirty years, their level of participation in the profession remains far below their representation in the general US population. While federal government data suggest that African - American men and women constitute over $11 \%$ of US business graduates, the AICPA estimates that only 4\% of the major firms' employment. Moreover, the rate of black CPA participation appears to fall as one's analysis moves up the ladder of the profession's largest firms. The AICPA reports that less than 1\% of the partners from the major firms are African - American accounting professionals. Our study seeks to answer two basic questions. One, why is the level of African - American participation in management of the major firms so low? Two, what actions should the major firms' leadership, African - American accounting practitioners, and accounting educators take to improve the level of African - American participation in management of the major firms? Our empirical data is drawn from three recent surveys of predominantly African - American accountants and a dozen structured interviews of a racially diverse group of Big 4 firm managers and partners. We reached three major conclusions. One, there are a disproportionately low number of African - American accountants in the management pipeline of the major firms. Two, our structured interviews with successful (managers and partners) accounting professionals of both races makes it clear that the road to management is a rigorous path for all professionals regardless of race. Three, many of the few black accountants within the major firms have become discouraged due to lack of key resources for success and search for other professional opportunities. Our conclusions form the basis for a variety of recommendations for employers, aspiring African - American professionals, established African - American accounting practitioners, the AICPA, the PCAOB.
\end{abstract}

The remainder of the paper is organized as follows. Section 1 presents a brief review of this paper's relevant research literature and the three research questions that are motivated by the results of our literature search. Section 2 describes the various survey designs and structure interviews that we used to gather this study's empirical data. We discuss our findings in Section 3. We offer some recommendations for corrective action in Section 4.

Keywords: Public Accounting; Career Advancement; African - American; Professional Services Firms

\section{INTRODUCTION}

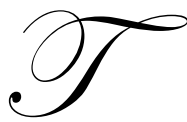

his paper seeks to examine the relationship between the level of management participation of African - American professionals and the promotion and retention practices within the US public accounting profession. Specifically, we found that less than $1 \%$ of the partners from the major US public accounting firms are African - American accounting professionals. Our study seeks to answer two basic questions. 
One, why is the level of African - American participation in management of the major firms so low? Two, what actions should the major firms' leadership, African - American accounting practitioners, and accounting educators take to improve the level of African - American participation in management of the major firms? Our paper proceeds from a review of a substantial and growing literature that examines the contemporary management development and promotion practices within large US public accounting firms. However, we were only able to find two published studies within this research literature that have sought to examine the impact of ethnicity on the professional development and promotion process within these firms. Much of the diversity oriented research that we reviewed has focused on describing the extent of African - American participation in the US public accounting profession. We used the results of our literature review to motivate our two primary research questions. Our study relies on 4 surveys and a series of structured interviews to generate the empirical basis for our findings and conclusions.

\section{SECTION 1: $\quad$ LITERATURE REVIEW AND RESEARCH QUESTIONS}

A substantial literature has developed describing the promotion and retention practices in the Big 4 firms. Chatman (1991) suggests that staff promotion and retention is a function of the convergence between the firm selection and socialization processes with the individual professional's values. Maxim (1996) examines the causes of turnover within the Big Six firms. Long hours, recurring deadlines, and a demanding work schedule were noted as the least enjoyable parts of a beginning accountant's work. Covaleski, Dirsmith, Heian, and Samuel (1998) describe the role of management by objective (MBO) motivated annual review and mentorship on the Big Six firms' promotion and retention practices. Guinn, Bhamornsiri, and Blanthorne (2004) found that a CPA certificate and an average of 13 years of professional experience with one or more firms are needed to become a Big Six audit partner. These studies emphasize that the major CPA firms tend to rely upon a rigorous up or out professional development model to manage their promotion and retention process. However, while these studies are part of an extensive and growing research literature seeking to examine the topic of personal advancement within the professional accounting environment, the impact of ethnicity on this process has only received very limited attention. Much of the diversity oriented research has focused on describing the extent of African - American participation in the US public accounting profession. Mitchell (1969) and Mitchell and Flintall (1990) used a survey methodology to find that African - American CPAs constituted less than 1\% of all American CPAs. Hammond (1997) and (2002) presents a series of oral histories that reports a pervasive environment of hostility toward African - American CPAs throughout the profession's largest firms for the bulk of the 20th century. Ross (2006) used an autobiographical chronicle to provide both a guide to professional career advancement as well as a description of the profession's transition to a corporate culture characterized by much more inclusiveness. Viator (2001) concludes that African-American public accounting employees are less likely to obtain an informal mentor and perceive greater barriers to obtaining mentors. Glover et al (2000) presents survey results that indicates African - American CPAs believe that the large firms are committed primarily to increasing the diversity of entry level ranks without a corresponding change in its managerial ranks.

Our review of the existing literature leads us to pose two basic questions:

1. Why is the level of African - American participation in management of the major firms so low?

2. What actions should the major firms' leadership, African - American accounting practitioners, and accounting educators take to improve the level of African - American participation in management of the major firms?

\section{SECTION 2 RESEARCH METHODOLOGIES - STRUCTURED INTERVIEWS AND SURVEYS}

This research relies on 4 surveys and a series of structured interviews to generate the empirical basis for our findings and conclusions. We briefly discuss the number of participants and their demographics of these surveys and structured interviews in Section 2. 


\section{Surveys}

In March 2005, the Howard University Center for Accounting Education (CAE) developed a questionnaire that solicited information on key factors contributing to the success of African Americans in the public accounting profession, including topic areas such as critical skills, work environment factors, social networks and mentoring. Participating public accounting firms were asked to distribute an e-mail invitation to their African-American professional employees inviting them to participate in the survey (African - American Public Accounting Firm Employee Survey). A cut-off date of April 1, 2005 was established. The completed survey was returned by each participant directly to Open Solutions, Inc, a Canadian firm specializing in performing surveys. The survey was online and web based. A total of 1,180 African Americans responded to the questionnaire. A report was published which summarized the survey's major findings (Annisette, etal 2005).

The 2006 National Association of Black Accountants (NABA) Membership Survey (2005 NABA Professional Member Survey) was developed by the CAE in May 2005. In November and December 2005, NABA distributed an e-mail invitation to its professional members inviting them to participate in the survey. The completed survey was returned by each participant directly to Open Solutions, Inc, a Canadian firm specializing in performing surveys. The survey was on-line and web based. A total of 427 NABA professional members responded to the questionnaire. The largest number of respondents was employed in public accounting - 42\%; 37\% worked in corporate accounting and $21 \%$ worked in government and not-for-profit firms. A report was published which summarized the survey's major findings (Ross and Wells, 2006).

2008 NABA Convention Survey was developed by the CAE in May 2008. We conducted a survey of the participants of the three executive training institutes at the 2008 convention of the National Association of Black Accountants. We received 153 useful responses. Ninety percent of our survey respondents were of African or African American decent. Over seventy percent (71\%) were female. Nearly two - thirds $(66 \%)$ of our survey respondents indicated that they were employees of the Big Four professional firms. Eighty percent of these survey respondents were either staff or senior level accountants. Over one - fifth $(22 \%)$ of our survey respondents had already passed the CPA exam (Stewart and Wells, 2008).

2010 African - American Accountants Exit Interview Survey was developed by the CAE in July 2010. 27 African - American accountants who left a public accounting firm in the previous 6 months responded to the six question survey.

\section{Structured Interviews}

2010 New Partners Group Interview was conducted by the CAE in July 2010. 4 African - American accountants who had been recently promoted to the partnership in one of the Big Four firms in the previous 6 months were interviewed as a group by CAE staff.

We conducted the 2009 Partners and Managers interview during February 2009 with 11 partners and managers who are currently employed by three of the Big Four firms and a former Arthur Anderson \& Co. partner who is currently a partner with a minority owned public accounting firm. Tables 1 highlight the demographics of these 12 professionals. 
Table 1 - Partners \& Managers Interviews Demographics

\begin{tabular}{|c|c|c|}
\hline \multirow[t]{4}{*}{$\square$} & \multicolumn{2}{|l|}{ Position } \\
\hline & घ & 7 partners \\
\hline & $\mathbf{\square}$ & 2 senior managers \\
\hline & [ & 3 managers \\
\hline \multirow[t]{3}{*}{$\square$} & Race & \\
\hline & $\mathbf{\square}$ & White $-75 \%$ \\
\hline & घ & African - American - $25 \%$ \\
\hline \multirow[t]{3}{*}{$\square$} & Sex & \\
\hline & $\mathbf{\square}$ & Male $-42 \%$ \\
\hline & $\mathbf{\square}$ & Female $-58 \%$ \\
\hline
\end{tabular}

\section{SECTION 3 MAJOR FINDINGS}

Macro level statistics compiled by the US federal government and the accounting profession itself suggests that there are a disproportionately low number of African - American accountants in the management pipeline of the major firms. Specifically, recent National Center for Educational Education statistics (2009) indicates that African American men and women constitute approximately $11 \%$ of all undergraduate business and MBA level graduates during the $2007-8$ academic year. However, African - Americans constituted approximately $7 \%$ of undergraduate accounting graduates during the $2007-8$ academic year (AICPA, 2009). Moreover, only $4 \%$ of the public accounting firms' 2008 new hires were African - American (AICPA, 2009). While this percentage is consistent with the overall participation of African - American professionals in the professional ranks of the major firms (those firms whose total employment exceeds 200 employees), approximately $1 \%$ of the major firms' partners were African - American. This finding of a small number of African - American partners was reinforced by our 2005 survey results where African - American professionals constituted less than $2 \%$ of survey respondents (Annisette, etal 2005).

The 2009 Partners and Managers interviews with successful (managers and partners) accounting professionals, who are both African - American and white, provided us with a wealth of informed comments about the promotion and professional advancement process within their firm. Table 2 highlights the career paths respectively of these 12 professionals.

Table 2 - Partners \& Managers Career Paths and Trajectories

\begin{tabular}{l}
\hline$\quad$ Time to manager \\
Average -8.75 years \\
$\square \quad$ Time to partner -5 to 14 years \\
$\quad$ Average -14.75 years \\
$\quad$ Range -7 to 19 years \\
$\square \quad$ Employment mobility - started professional career with a different employer \\
$\quad 3$ of 7 partners \\
$\quad 2$ of 5 managers and senior managers
\end{tabular}

Our findings from this analysis of the work histories of our 12 structured interview respondents from the 2009 Partners and Managers interviews reinforced the findings of Guinn, Bhamornsiri, and Blanthorne (2004). Specifically, it takes more than a decade of progressive professional work experience to reach partnership in the major firms. Our findings also reinforced the findings of Guinn, Bhamornsiri, and Blanthorne (2004) that many partners and managers started their career outside of public accounting or started with another CPA firm.

We found a considerable consensus among our structured interview participants about the promotion process across time, different firms, and individual experiences. The road to management is a rigorous path for all professionals regardless of race. Major landmarks on the road to professional advancement in public accounting include: 
a. Pass the CPA exam early in your career. Coming to a firm with a CPA certificate in hand or passing the exam early in one's career marks a junior accountant as a player in the game. Not passing the exam within a couple of years can lead to marginalization of a staff accountant.

i. $\quad$ "I was really glad that I studied for and passed the CPA exam while I was a tax accountant with a Fortune 500 corporation. I would have been hard pressed to find the time to study for the exam while working as a senior at a Big Four firm."

ii. "They (my first employer, a Midwestern based regional CPA firm) treated staff accountants who failed to passed the exam really bad." Those guys stopped getting the plum assignments. Nobody wanted to work with them if they didn't have to!"

b. $\quad$ Become technically strong and be branded for it

i. "As a staff accountant I made myself into the in house expert on A133 governmental audit work. Over the years everyone from the firm's managing partner on down would call me about A133 regs and rules."

c. Perform well on your initial assignments to build a positive reputation

i. "You need to get your initial assignments done right and on time."

ii. "You could be green or purple but people (i.e. managers and partners) would ask for you if you could get the job done right and on time."

d. Attract and cultivate a mentor/sponsor to obtain career building assignments

i. "The sponsor that you need will find you if you have a reputation for good performance.... even if you are a four eyed purple monster.”

ii. "My mentor was the only female audit manager in the office... She gave me opportunities and assignments that I might not otherwise have had."

e. Develop your own timetable for advancement with your supervising partner.

i. "I couldn't tell you the number of times (in partners' meetings) that I heard that 'so and so shouldn't be promoted because he didn't ask for it'."

ii. "You got ask to be promoted and develop a plan to get you there, working in concert with your manager or partner."

f. Learn to live an "unbalanced" life

i. "I don't believe that work and my personal life can ever be fully balanced. There is a pendulum that swings focus between work and play... I stay determined to keep weekends for the family."

ii. "There is no such thing as 'work/life balance' when that report is due! You got to get it done on time! .... However, my partner will let me work from home a lot outside of the busy times."

iii. "As a senior auditor, I was under a lot of stress, with multiple small audit engagements, which seemed to drag on and overlap. I was working a significant amount of overtime, and as a result, considered leaving to improve work/life balance. However, after working through the backlog of engagements, I realized that I really liked the technical aspects and "challenge" of the job, and knew that I had more to learn - so I decided to say until I believed I had learned everything that I needed to know. I'm still learning - so I'm still here!"

We use these findings and observations from our successful (i.e. manager or partner level) accountants to establish a model of professional success. 


\section{An Individual Perspective on Career Advancement in Public Accounting}




In this paper we use this model as a qualitative standard against which we measure the progress of a group of African American accountants. Methodologically, we incorporated the findings of four previously mentioned surveys in order to measure the progress of our predominately African - American accountants sample relative to the standards implied by our model.

Table 3 below summarizes the employment tenure of these four surveys.

Table 3 - HU CAE Sponsored Surveys Employment Tenure Features

\begin{tabular}{|c|c|}
\hline & $2005-1180$ African - American respondents \\
\hline & $-82 \%$ with 5 yrs or less \\
\hline$\square$ & $\begin{array}{l}2006 \text { - } 427 \text { NABA professional members } \\
\text { Time with current employer - } 69 \% \text { with } 5 \text { yrs or less }\end{array}$ \\
\hline$\square$ & $\begin{array}{l}2008 \text { - } 152 \text { NABA professional members } \\
\text { Time with current employer - } 75 \% \text { with } 3 \text { years or le }\end{array}$ \\
\hline & $\begin{array}{l}2010 \text { - } 27 \text { African - American exit survey respondents } \\
\text { Time with former employer - } 84 \% 5 \text { years or less }\end{array}$ \\
\hline
\end{tabular}

Table 3 findings suggest that the large majority of our survey respondents have either recently changed employers or recently entered the profession.

The key survey findings are summarized below in Table 4. In many areas these findings contrast sharply with the prospective recommendations offered by the professional success model provided by our structured interviews. This contrast suggests that a large number of African - American staff and senior accountants are off track for management positions in the major firms in which they work.

Table 4 - HU CAE Sponsored Surveys Major Findings

Over $60 \%$ have not passed CPA by their 2nd year with their current employer (Annisette etal, 2005) and (Ross and Wells, 2006).

Our survey findings indicate that most of our survey respondents who are probably staff level accountants have not passed the CPA exam during the crucial first two years with their current employer. Our model predicts that the failure to pass the CPA exam within this period of time will contribute to the marginalization of a professional within their firm.

Nearly $50 \%$ do not feel fully accepted by colleagues, and lack access to firm's networks (Annisette etal, 2005) and (Ross and Wells, 2006).

Many African - American accountants feel isolated and out of the political loop needed for advancement. Failure to pass the CPA exam will contribute to this isolation but does not fully explain this feeling of isolation. 10 of the 14 black accountants $(71 \%)$ who were CPAs reported feeling of isolation from their peers, supervisors, and their firm's key social networks in the 2010 Exit Interview Survey.

Only 40\% report involvement in fruitful mentoring relationship (Annisette etal, 2005) and (Ross and Wells, 2006).

The ideal mentor in public accounting is both an intimate counselor as well as a well placed advocate for the rising accounting professional. Such counsel is especially valuable to the young African - American professional who comes to the profession with very little exposure to its prevailing culture. Moreover, the mentor can provide a staff or senior level professional with frank performance feedback that may be difficult to find elsewhere. A good sponsor will speak up on behalf of a rising professional in staffing meetings to help a junior or senior accountant obtain the key job assignments that are essential to building a successful track record and reputation. The common lack of such a valuable resource suggests that many rising African - American professionals are forced to rely on their own counsel and self promotional activities - a very daunting proposition. Moreover, Annisette etal, 2005 concluded that as employees advanced in their careers, the percentage who agreed that they benefited from a fruitful mentoring relationship within their current work environment steadily increased - from $42 \%$ of staff members to an overwhelming majority (90\%) of partners. This conclusion was reinforced in the 2010 new partners' group interview. All four respondents reported that 
they had sought out and worked with a mentor. All four new partners rated their mentor's performance absolutely critical to their career success.

More than $40 \%$ report personnel evaluations are inaccurate \& unfair (Stewart and Wells, 2008).

Many staff level professionals feel that they are not receiving the personnel evaluations that their performance warranted. Nevertheless, formal personnel evaluations represent the official internal mechanism for compiling and communicating an individual professional's performance reputation. In this context, an unfair and inaccurate evaluation would clearly limit the future promotion prospects of the junior level staff who received a less favorable supervisory assessment.

Over 50\% feel they don't receive assignments they need to advance (Annisette etal, 2005), (Ross and Wells, 2006), and (Stewart and Wells, 2008).

The majority of respondents feel that they are not receiving the experiences that they will need to excel. This finding appears to reflect to cumulative impact of low CPA exam passage, lack of fruitful mentorship relationships, low performance evaluations, and isolation from their firm's key social networks. An assignment to the firm's key jobs are hard to obtain if the professional isn't certified, lacks an effective sponsor, lacks a reputation of high performance, and is isolated from their employer's key internal networks.

Nearly $70 \%$ report intention to leave current employer within five years (Stewart and Wells, 2008).

Our success model and related statistics suggest that generally takes more than five years for a junior accountant to rise to management. This finding suggests that the majority of respondents are planning to leave their current employer before reaching management.

The culmination of their frustrations has apparently lead most black accountants in our survey to think of other career options well before they can reach management level positions within their firm. The 2010 African American Exit Interview Survey provides direct if limited empirical data reflecting why African - American accountants actually left their positions in the major accounting firms. The top four reasons for leaving public accounting given by survey respondents are:

$44 \%$ cite a desire for a better "work / life" balance

$20 \%$ report that they are seeking work experiences outside of the public accounting profession

$8 \%$ cite a desire to continue their graduate education.

$8 \%$ expressed a desire to leave an uncomfortable organizational culture.

\section{SECTION 4 RECOMMENDATIONS FOR CORRECTIVE ACTIONS}

Finally, we have prepared a series of recommendations designed to help improve the level of management participation of African - American CPAs in the nation's leading public accounting firms.

Recommendations for Employers

Sponsor pre-employment CPA prep courses. Early passage of the CPA exam is the foundation for career success in the profession. The current structure of the uniform CPA examination together with the pre hire's participation in a rigorous prep program can facilitate the early achievement of this key hurdle.

Improve diversity and management training of first line supervisors and managers.

Develop procedures to ensure minority accountants' participation in key job assignments, and fairness in performance evaluations.

Include minority professional staff retention objectives in partners' MBO evaluation and compensation packages. 
Recommendations for Aspiring Professionals

Prepare to take and pass the CPA exam prior to employment.

Actively manage your careers.

Seek out promotional opportunities both within and outside of your current employer.

Continue to improve your technical knowledge, leadership skills, and community involvement.

Aggressively build relationships with key individuals of all backgrounds, including your peers.

Recommendations for Established African - American Accounting Practitioners

- Maintain high profile both inside and outside the firm with junior African - American professionals.

- Actively mentor and sponsor junior African - American professionals.

Recommendations for AICPA \& PCAOB

The PCAOB should include the minority professional staff retention as a quality metric in its inspection programs of public company auditing firms.

- The AICPA should commission and publish research studies that identify best practices for the recruitment and retention of minority professionals.

\section{AUTHOR INFORMATION}

Louis J. Stewart, PhD CPA is an associate professor of Accounting at the School of Business at Howard University. He earned his master's degree in business administration from the University of Chicago. Following his graduation Louis has worked in various roles in financial management of Chicago area nonprofit community ending with the position of chief financial officer of the Englewood Community Health Organization over the next seventeen years. He earned his CPA during this time period. Louis prepared himself for a second career in higher education by earning a doctorate in business administration from the University of Wisconsin in Madison. E-mail: 1_stewart@howard.edu

Jean Wells, JD CPA a CPA and attorney, is an Assistant Professor at Howard University School of Business where she teaches tax and accounting courses. Ms. Wells is the faculty advisor for Beta Alpha Psi, the accounting honor society and program coordinator for the Volunteer Income Tax Assistance program. Ms. Wells earned a Bachelor's in Business Administration (B.B.A.) Accounting from Howard University and a Juris Doctorate from George Washington University. Before joining the faculty full-time at Howard University, Ms. Wells was a manager in Deloitte's Washington National Tax Policy Services Group where she covered IRS, Treasury, and legislative tax developments. E-mail: jwellsjessup@ howard.edu

Frank Ross, MBA CPA is a visiting professor of Accounting and Director, Center for Accounting Education at the School of Business at Howard University. He retired from KPMG IN December 2003 after providing 38 years of service. Prior to retiring, Frank was the Mid Atlantic Area Managing Partner for Audit and Risk Advisory Services and the Managing Partner for the Washington DC offices of KPMG LLP. He was also elected to the KPMG US Board of Directors the KPMG Americas Board. Frank has also served as chairman of the Board of the KPMG Foundation. E-mail: f_ross@howard.edu 


\section{REFERENCES}

1. Annisette, M.; Ross, F.; and Wells, J. 2005 "The Professional Experiences of African - American Accountants: Analysis of Survey Results" Howard University Center for Accounting Education Washington DC 2005

2. Chatman, J. A. 1991 "Matching People and Organizations: Selection and Socialization in Public Accounting Firms" Administrative Science Quarterly, Vol. 36, No. 3, pp. 459-484

3. Covaleski, M. A.; Dirsmith, M. W.; Heian, J. B.; and Samuel, S. 1998 "The Calculated and the Avowed: Techniques of Discipline and Struggles Over Identity in Big Six Public Accounting Firms" Administrative Science Quarterly, Vol. 43, No. 2, Special Issue: Critical Perspectives on Organizational Control, pp. 293327

4. Glover, H. D.; Mynatt, P. G.; and Schroeder, R. G. 2000 “The Personality, Job Satisfaction, and Turnover Intentions of African - American Male and Female Accountants: An Examination of the Human Capital and Structural/Class Theories" Critical Perspectives on Accounting Volume 11 Pp. 173 - 92.

5. Hammond, T. D. 1997. From complete exclusion to minimal inclusion: African-Americans and the public accounting industry, 1965-1988. Accounting, Organization and Society 22 (1): 29-54.

6. Hammond, T., (2002) A white-collar profession: African American Certified Public Accountants since 1921. USA: University of North Carolina Press.

7. Mitchell, B. and Flintall, V. 1991 "The Status of the Black CPA: Twenty Year Update" Journal of Accountancy. Vol. 170, Iss. 2; pg. 59 - 66.

8. National Center for Education Statistics 2009 "Table 26.2: Percentage of degrees awarded by degree granting institutions in most popular fields of study, by race/ethnicity and level of study: 2007 - 8" Status and Trends in the Education of Racial and Ethnic Minorities US Department of Education Institute of Education Science

9. Reigle, D. R. 2009 "2009 Trends in the Supply of Accounting Graduates and the Demand for Public Accounting Recruits" American Institute of Certified Public Accountants, Inc. New York, New York $10036-8775$

10. Ross, F. K. (2006) Quiet Guys Can Do Great Things, Too: A Black Accountant's Success Story. Writing Our World Press

11. Ross, F. and Wells, J. 2006 "An Analysis of the Professional Work Experiences of NABA Members" Howard University Center for Accounting Education Washington DC 2006

12. Stewart, L. and Wells, J. 2008 "2008 NABA Convention Survey” Howard University Center for Accounting Education Washington DC 2008

13. Viator, R. E. 2001 "An Examination of African Americans' Access to Public Accounting Mentors: Perceived Barriers and Intentions to Leave" Accounting, Organizations and Society Oxford Vol. 26, Iss. 6; pg. $541-58$. 